\section{Wagons and chariots}

\section{A.F. Harding}

The Earliest Wheeled Transport: From the Atlantic Coast to the Caspian Sea.

By Stuart Piggott. Thames and Hudson: 1983. Pp.272. £20, \$34.95.

THE WHEEL is one of those technological inventions which, in the banal and illogical catch-phrase, 'changed the course of history'. What would Old World civilization have been like without it? What would the New World have been like with it? Wheels are among those devices, such as pottery or writing, that are so basic one cannot easily imagine life without them. In view of this, it is surprising that no modern monograph has hitherto been devoted exclusively to the early history of wheeled transport, and a long-standing gap is thus filled with the appearance of the present work.

Professor Piggott is no stranger to the literature on the subject: he has been writing about prehistoric wheels since 1949 and in his wide range and detailed knowledge of the subject has no rival. As often happens, a number of recent books have dealt with aspects of the same problem, and here mention must be made of M.A. Littauer and J.H. Crouwel's Wheeled Vehicles and Ridden Animals in the Ancient Near East (Brill, 1979), Crouwel's Chariots and other means of Land Transport in Bronze Age Greece (Allard Pierson, 1981), and volumes in the series Prahistorische Bronzefunde dealing with the Italian vehicles (E. Woytowitsch) and early horse harnesses (H.-G.Huttel).

But Piggott is concerned to write a connected narrative tracing the development of wheeled transport from earliest times
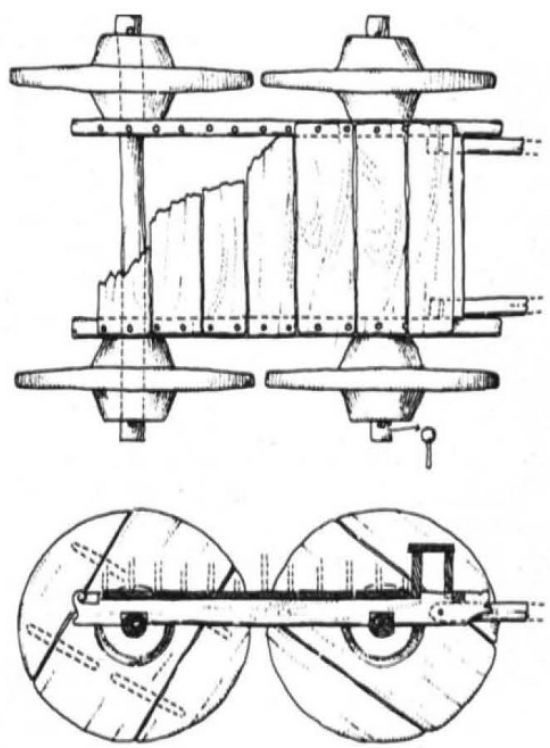

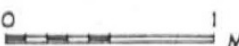

down to Classical Antiquity, and this he does in typically thorough and workmanlike fashion, apparently equally at home in the unfathomable awfulness of Russian excavation reports of 3 rd millennium " $\mathrm{Pit}$ Grave" vehicles and in the complexities of Iron Age wagon burials in central Europe. Thus we progress from early solid-wheeled wagons which would have been pushed to travel at walking pace, no doubt used for getting the hay in and the manure out, through the first spoked wheels as seen on Bronze Age chariots, to the marvellous and complicated carriage of Dejbjerg, with its roller bearings and pivoted front axle. The progression is not merely technological: the social effects of wheeled transport are in many ways the most important thing about it, as chieftains and other elite groups contrived to make their status manifest by riding, and eventually having themselves buried, in or with wagons and chariots.

In spite of the 'coffee-table' appearance this is a specialist's book which the layman may find hard going in parts. Careful study will however repay the effort, for this is a mine of information on many subjects. It is worthy of note that Piggott relies almost entirely on radiocarbon dates for the earlier periods, a position which will not find favour on the European continent. Nor will Near Eastern specialists care for: "The absolute chronology of Bronocice is more reliable than that of Uruk IV or the Early Dynastic periods of Mesopotamia".

One topic that I feel should have been more fully covered is Aegean Bronze Age chariots, but this is a relatively small failing in such a feast of learning and wisdom. The book is beautifully produced (in Hungary) and marks a worthy culmination to the author's long and painstaking work in such an important area of technology.

A.F. Harding is a Lecturer in A rchaeology at the University of Durham and a specialist on European Bronze Age archaeology.

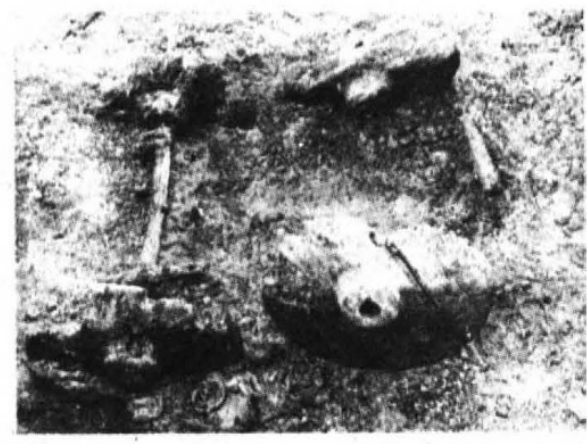

Above: Remains of a wagon from the second millenium BC found at Trialeti, Georgian SSR.

Left: Scale drawing of a wagon from the same site.
New ideas

\section{- new science}

J.Z. Fullmer

The Revolution In Science 1500-1750.

By A. Rupert Hall.

Longmans: 1983. Pp.373. f8.95.

IN 1954 Longmans published A. Rupert Hall's The Scientific Revolution, 15001800, a work so well received that 1962 saw a second edition. The book under review is a heavily revised third edition. Only two chapters, that on the influence of technology on scientific development, and that on 'The Range of Life', remain close to their 1962 version. Hall was moved to drastic revision - as reflected in the changed title - by his desire to mirror "the increased maturity of studies of sixteenth and seventeenth century science". To accommodate this new scholarship, Hall has lopped off the last half of the eighteenth century, along with discussion of the changes operating in chemistry and in the electrical sciences.

What scholarly studies moved Hall to change his emphasis? 'Notes' appended to each chapter provide clues toward an answer. For Galilean studies the work of Stillman Drake; for Newtonian studies, the work of D.T. Whiteside, of A.R. and M.B. Hall, of B.J.T. Dobbs, and of R.S. Westfall; for biological investigations, the work of Walter Pagel. The list could be extended from Hall's 'Notes' to the sections on the organization of science, on Copernicus, on Kepler, on Tycho Brahe, and the like. Still, the list, while understandable - for the work of these distinguished scholars certainly must be taken into account in any text on the scientific revolution - raises a serious question. Does the reader assume that changes in chemistry and in electrical studies are not part of 'the scientific revolution', or does the reader assume that scholarly definition of the term has been revised to exclude changes that appeared in these two disciplines? Hall does not address this question directly. Therefore, the reader familiar with the earlier edition is left with an impoderable; there is no way of knowing what has prompted the exclusion of these fields.

While some sections have been expanded (and others truncated) some new scholarship has been accommodated, and there is now a mountain of papers and books bearing on his topics and periods which Hall has neglected. What has remained constant is Hall's attitude and his range of view. He avers that he wrote about ideas rather than about society, and about particular individuals rather than about anonymous masses. Early in the text (p.2) he announces that he "unashamedly" follows "a positivist or even whiggish line". He asserts his belief in "progress" 
and is convinced that "in the systems of scientific knowledge progress can be measured in terms quite independent of value judgments" (p.4). Newton's worldview, he argues, represents progress over Aristotle's because "Newtonian theory is bigger, more exact, more precisely testable, and above all more mathematical than its predecessor." Hall views the history of science as a branch of the history of ideas. Surprisingly, he equates the force of Newtonian ideas with the force of Lenin's ideas (p.360).

Hall has ignored, or rather, neglected to include in his treatise any accounts of the social relations of science, and little of the political relations. Martin Luther, for example, warrants mention only three times, and these mentions are incidental; it is not until page 348 that the reader is reminded that war separated the French and the English from 1698 to 1714. Hall's second chapter, 'The Problem of Cause' may be regarded as an attempt to deal with the issues raised by the sociologists of science, but most of the scholarship is dealt with indirectly, by refutation. The reader is told why Thomas Kuhn's The Structure of Scientific Revolutions (University of Chicago) should not be applied to the scientific revolution of $1500-1750$ but Kuhn's work is not directly cited in this connection (citations to it do appear elsewhere). Merton's thesis about the role of Protestants in the founding of the Royal Society is rejected, although there is an acknowledgement that Christopher Hill and Charles Webster have found it seminal. Hall deals handsomely with Dame Frances Yates's magisterial Giordano Bruno (Routledge), but rejects its operating thesis. These are, of course, exactly the positions to be expected from someone who sees the history of science as a sub-set of the history of ideas.

In sum, Hall's book tacitly redefines the term 'scientific revolution' by concentrating almost exclusively on changes in astronomy, mechanics and biology, removing from consideration changes in chemistry and electricity; the scientific revolution is seen as a triumph of mathematicization, as the progress of rationality over religiosity, above all, as an 'internal' process depending almost exclusively on 'progress' within a discipline. There is no doubt in this reviewer's mind that if what is wanted is such an 'internal' history, Hall's book is one of the best of the genre. The prose is lucid, the structure of each chapter (and of each paragraph) is rhetorically exemplary and graceful. Graduate students, those with some knowledge of the literature, should find the book rewarding reading; undergraduates will be confused by it. Non-historians, especially those with 'internalist' or whiggish proclivities will find here storng confirmation of their own convictions.

J.Z. Fullmer is a Professor of History at the Ohio State University, Columbus, Ohio.

\section{The ascent of}

\section{man}

\section{Robert Fox}

The Montgolfier Brothers and the

Invention of Aviation 1783-1784.

By Charles Coulston Gillispie.

Princeton University Press: 1983. Pp. 210. \$45, £30.20.

THE first public demonstration of a hot-air balloon took place on 4 June 1783 at Annonay in France. The setting, in a remote, hilly part of what is now the department of the Ardèche, was an improbable one, and the curious onlookers who gathered in the town's square could hardly have appreciated the momentousness of a flight that lasted a mere ten minutes and ended frighteningly with the sackcloth and paper of the balloon's fabric set alight by the fire of its brazier. But within weeks the brothers who mounted the demonstration, Joseph and Etienne Montgolfier, had leapt from provincial obscurity to the rank of national celebrities, and they have remained celebrities ever since.

Charles Gillispie devotes the greater part of his gracefully written book to an account of the circumstances of the Montgolfiers' invention and of the early heroic years of aviation in France. It is a story bristling with dramatic events and colourful characters. From the start, spice was added to the episode by the initial, mistaken assumption of the Parisian savants that the Annonay balloon must have been raised by hydrogen. The result was a rivalry, which the Montgolfiers never sought, between the

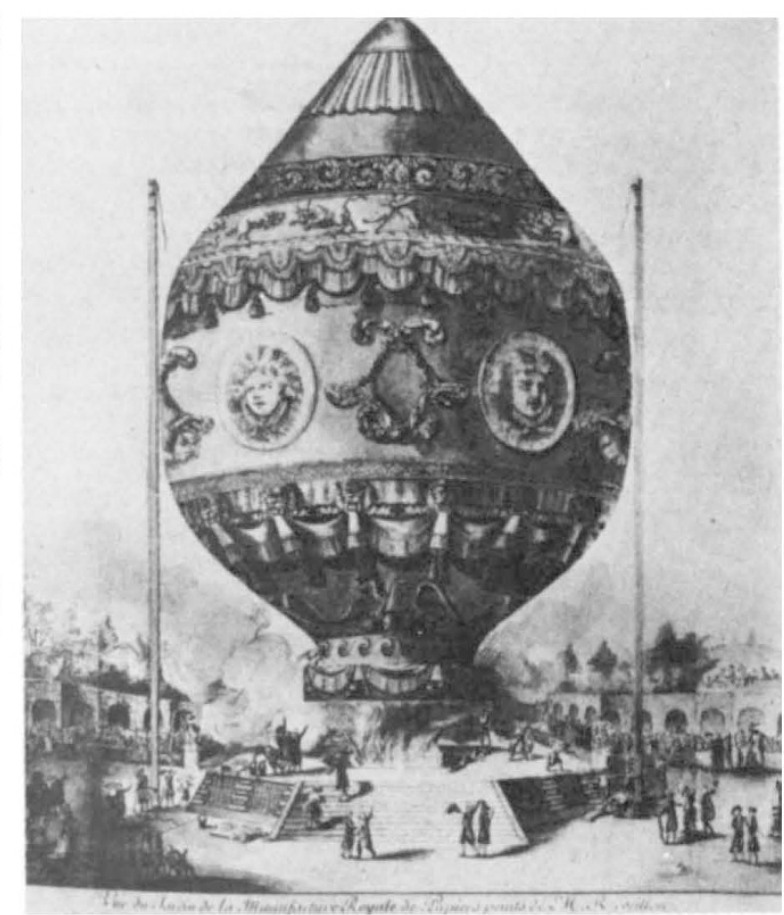

Testing an early balloon - October 1783. hot-air montgolfière and the hydrogen balloon, or charlière, named after the physicist J.A.C. Charles, who was a notable pioneer of hydrogen ballooning.

The degree of popular interest was extraordinary, and grand public demonstrations became the order of the day. In September 1783, Etienne Montgolfier staged a particularly memorable flight for the king and queen at Versailles and on 21 November 1783 the inevitable next step was taken when a prominent scientific lecturer, Pilatre de Rozier, and an infantry officer, the marquis d'Arlandes, undertook the first manned flight in an untethered balloon. Ironically, it was Pilatre de Rozier who became the first victim of aviation in June 1785, when his hazardous attempt to use a hydrogen balloon and a hot-air balloon in tandem ended in an all too predictable disaster. But even that wellpublicized tragedy did nothing to dampen enthusiasm. Ascents continued to attract large crowds, and the risks only added to the stature of professional aviators, several of whom earned a good living by their displays. The public's appetite for daring deeds was insatiable until well into the nineteenth century, and it is only surprising that accidents (such as the one that led to the death of the colourful Madame Blanchard as she injudiciously enlivened her ascent in a hydrogen balloon by letting off fireworks) were so few in number.

The conviction that ballooning quickly became an altogether too sensational affair is unavoidable. This was certainly the view of the Montgolfiers, whose hearts and principal means of livelihood remained in their paper-making business back in the Vivarais, and the high jinks and attractive iconography have been a snare for historians ever since.

But this book dispels the idea that early ballooning was nothing more than an unscientific activity divorced from all seriousness. The reinterpretation is an important one, resting on printed sources, letters, and notebooks that have been hitherto unread or inadequately exploited; and it appears unchallengeable. The theoretical content of the Montgolfiers' work may have been unconventional, but it was substantial and, in significant respects, original, as Gillispie demonstrates. He shows Etienne Montgolfier engaged in calculations of the lifting power of balloons ('the bigger the better' was the gist of his conclusions) and embarking on the design of paddles for a dirigible balloon. And, most interestingly, he points to 